\title{
INDUSTRY "SCIENTIFIC RESEARCH AND DEVELOPMENT" AS ECONOMIC UNIT IN THE BALTIC STATES AND FINLAND
}

\author{
Andrejs Jaunzems \\ Ventspils University of Applied Sciences, Latvia \\ jaunzems@venta.lv
}

\begin{abstract}
The goal of the paper is to carry out a comparative dynamic analysis of industry's M72 (Scientific research and development) input and output in the Baltic States and Finland as part of their national and global economies. From more practical point of view the goal of the research is to estimate the economical efficiency of industry M72 in Latvia. The empirical material of the research is the National Input-Output Tables for the Period of 2000-2014 available on the World Input-Output Database with unified structured statistical information in monetary terms. The theoretical background of the research is the Input-Output analysis, which is examined, for example, in Input-Output Analysis. Foundations and Extensions, a significant contribution by Ronald E. Miller and Peter D. Blair. The original version of the model created by the author allows to calculate and to interpret the interindustry coefficients, Leontief inverse, allocation coefficients and Ghosh inverse. The author conducts the analysis of the industry's M72 gross output, final demand, value added, direct and total backward linkages, direct and total forward linkages to estimate the role of the industry M72 in the national economy. The main conclusions of the study apply the sales structure of M72 gross output and M72 value added forming. The analysis of basic factors, which influenced the industry's operating efficiency, mostly concerns the subindustry M72.2 (Research and experimental development on social sciences and humanities) in Latvia.
\end{abstract}

Keywords: industry M72 (Scientific research and development), Input-Output model, value added, interindustry coefficients, Leontief inverse, allocation coefficients, Ghosh inverse, credence goods.

\section{Introduction}

The aim of the presented study paper is to carry out a comparative analysis of the industry's M72 (Scientific research and development) input and output in the Baltic States and Finland as part of their national and global economies. The main questions are: how do input and output of the industry M72 form, what is the gross output sales structure, what are the sources for value added formation. From a more narrow practical point of view, the goal of the study is to estimate, in the sustainability context, the economic efficiency of industry M72 in Latvia.

The empirical material of the study is the National Input-Output Tables for the Period of 20002014 (NIOT) available on the World Input-Output Database (WIOD) with unified structured statistical information in monetary terms (www.wiod.org). Data for 56 sectors are classified according to the International Standard Industrial Classification (ISIC), revision No. 4. The products are classified according to the statistical classification of products by activity, abbreviated as CPA. Classification of products (goods and services) covers 56 product categories following the primary outputs from 56 sectors. NIOTs are compiled in current prices, expressed in millions of US dollars. The Input-Output tables have an industry-by-industry format as many applications require such a square matrix reflecting the economic linkages across industries. It represents the direct and dual systems of accounting balancing equations. The latest NIOT available right now is for 2014. Nevertheless, this is the reason to expect that WIOD will also be carried on in the future and WIOD will grow as a very fruitful empirical inventory for scientific and management needs.

The comparative dynamic approach allows us to recognize differences and analogies in the structure of the industry's M72 average expenditures vector and in the structure of average revenues vector in the Baltic States and Finland during 14 years.

We see NIOT as a reliable source of information and would like to accept NIOT as indisputable. However, during current studies the curiosity appeared, namely, the Lithuanian account CONS_g (Final consumption expenditure by government) for M72 during 2000-2014 contains only the zero sums of money. Obviously, this is a mistake. We tried to obtain an explanation with help of the Lithuanian Ministry of Education, Science and Sport (smmin@smm.lt), but so far, no success.

The general theoretical background of the current study in the wide sense is the Input-Output analysis offered by Leontief [1] and Ghosh [2]. The current content of the Input-Output analysis is examined, for example, in Input-Output Analysis. Foundations and Extensions by Ronald E. Miller, Peter D. Blair [3], and in a number of other publications as well. The theoretical framework of this 
paper is directly related to the theoretical background of the paper by Jaunzems (2018), where the original Input-Output model adapted for NIOT is offered. The original version of the Input-Output model allows to calculate and to interpret the interindustry coefficients, Leontief inverse, allocation coefficients and Ghosh inverse. In addition, some tools of descriptive statistics are used in this paper.

The main conclusions are the following. In Latvia the product of industry M72 is practically not sold on the market as intermediate consumption resource for industries of the national economy. In 2014 about $11 \%$ of gross output are sold in the foreign markets as an export product. About $88 \%$ of industry's M72 gross output is bought from non-market institutions CONS_g (Final consumption expenditure by government) and GFCF (Gross fixed capital formation), therefore, the basis for value added formation in M72 mainly consists of grants. By definition, a grant is some non-repayable amount of money that a government or other institution presents to an individual or to an organization for a particular manipulated purpose, such as education or scientific research and experimental development.

Figure 1 contains the diagram "Share of the intermediate consumption and value added from the total output of M72 sector", calculated by Timmer, Dietzenbacher, Los, Stehrer, \& de Vries (2015) [4], using the World Input-Output Database (WIOD) for the period of 1995-2011. Figure 1 visually shows that intermediate consumption of industry's M72 product as percentage of M72 gross output in Latvia (LVA) is the smallest one. Let us try to interpret and explain this fact.

Note. All tables and figures (except Figure 1) in the current paper are created by the author using NIOT, mathematical models and Microsoft Excel tools.

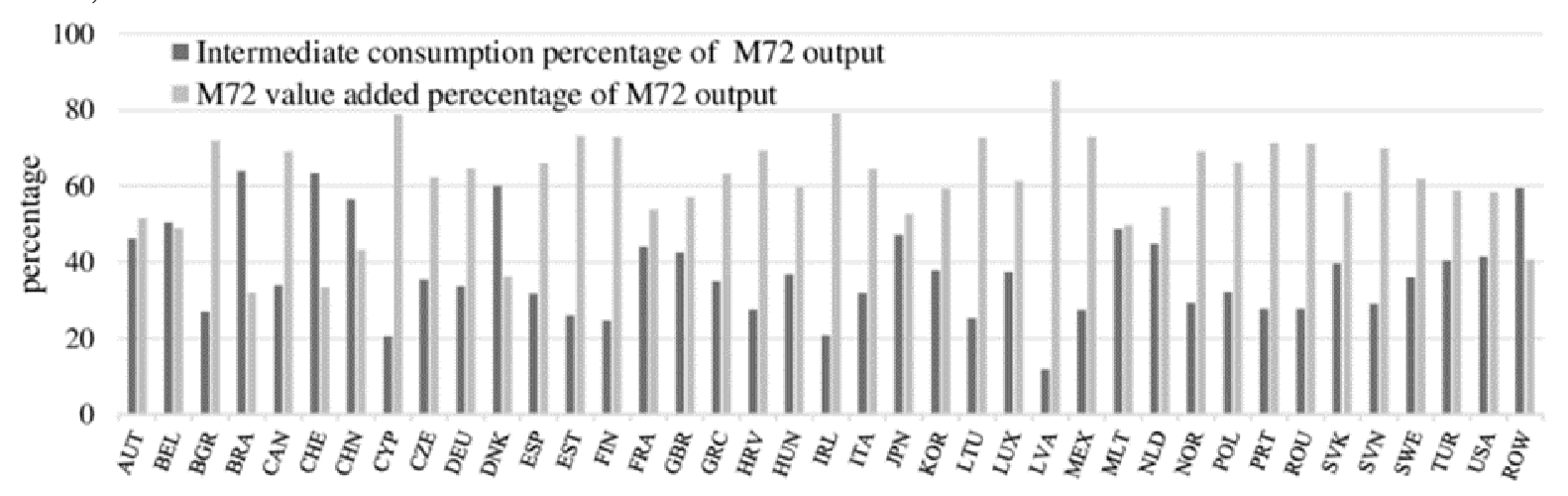

Fig. 1. Share of the intermediate consumption and value added from the total output of M72 sector. Source: [4] Timmer, Dietzenbacher, Los, Stehrer, \& de Vries (2015)

\section{Materials and methods}

As mentioned in the introduction, the empirical material of the study is the National Input-Output Tables for the Period 2000-2014 (NIOT) available on the World Input-Output Database (WIOD) with unified structured statistical information in monetary terms (www.wiod.org) [5]. Values are denoted in millions of US dollars. The United Nations' 3-letter codes are used: EST (Estonia), FIN (Finland), LVA (Latvia), LTU (Lithuania). The main tool applied in the current study is the original version of the Input-Output model specifically constructed by [6] with regard to the given structured statistical information NIOT.

Let us shortly expound the theoretical input-output framework, key concepts, and methods used in connection with the structure of the given NIOT information.

Let us assume that the open national economy is categorized into $\mathrm{n}$ sectors (industries). The inputoutput price model based on monetary data in current prices is constructed by using the national account's balancing equations concerning the definite time period.

We consider the industry as an abstract subject-producer that has to hold the equilibrium balance: for each monetary unit produced the sum of purchasing expenditures (intermediate consumptions) plus value added equals the sum of sales revenues.

Let $i, j=1,2, \ldots, n$.

1. The structure of the equation 


$$
x_{1 j}+x_{2 j}+\ldots+x_{n j}+z_{1 j}+z_{2 j}+\ldots+z_{n j}+V A_{j}=G O_{j}
$$

characterizes the domestic and imported input used for producing in the $j$-th industry $G O_{j}$ monetary units of gross output.

Here $x_{i j}$ is the domestic intermediate consumption indicator, what shows how much (in monetary terms) the i-th industry's product is bought from the $j$-th industry in order to attain its gross output $G O_{j}$. Indicator $z_{i j}$ shows the volume of imported $i$-th industry's product bought from the $j$-th industry in order to attain the gross output $G O_{j} . V A_{j}$ is the value added in the $j$-th industry. The vector-column $\left(x_{1 j}, x_{2 j}, \ldots, x_{n j}, z_{1 j}, z_{2 j}, \ldots, z_{n j}, V A_{j}\right)^{T}$ shows the production costs for producing gross output $G O_{j}$, and value added created withal. This vector indicates the expenditures structure of $j$-th industry in order to produce its gross output $G O_{j}$ and is determined by the technological standards and specifications of jth industry, and the capacity of the domestic economy.

2. The structure of the equation

$$
x_{j 1}+x_{j 2}+\ldots+x_{j n}+F D_{j}=G O_{j}
$$

characterizes the use of the gross output $G O_{j}$ of the $j$-th industry as a sum of domestic intermediate consumptions and final demand. Here $z_{j k}$ is the volume of the $j$-th industry's product bought from the $k$-th domestic industry to ensure its gross output $G O_{k}$. $F D_{j}$ is the volume of $j$-th industry product sold to the final consumers. The most important parts of the final demand $F D_{j}$ are the purchases of the institutions: CONS_h (Final consumption expenditure by households), CONS_g (Final consumption expenditure by government), GFCF (Gross fixed capital formation), CONS_np (Final consumption expenditure by non-profit organisations serving households), EXP (Exports).

Let us interpret the vector-row $\left(x_{j 1}, x_{j 2}, \ldots, x_{j n}, F D_{j}\right)$ as the sales revenue vector of the $\mathrm{j}$-th industry with respect to its gross output $G O_{j}$.

3. It should be emphasised that each industry as the purchaser-producer-seller holds the equilibrium balance - the sum of purchasing expenditures equals the sum of sales revenues:

$$
x_{1 j}+x_{2 j}+\ldots+x_{n j}+z_{1 j}+z_{2 j}+\ldots+z_{n j}+V A_{j}=x_{j 1}+x_{j 2}+\ldots+x_{j n}+F D_{j}=G O_{j} .
$$

It is well-known that in market economy it is easy to buy and difficult to sell. Economists are more concerned about chances to get revenue $x_{j 1}+x_{j 2}+\ldots+x_{n}+F D_{j}$ than about the perspectives of purchases $\left(x_{1 j}, x_{2 j}, \ldots, x_{n j}, z_{1 j}, z_{2 j}, \ldots, z_{n j}\right)$.

Better sales conditions ensure a bigger sum $x_{j 1}+x_{j 2}+\ldots+x_{j n}+F D_{j}$, but better purchasing conditions and more efficient production technology ensure a smaller sum $x_{1 j}+x_{2 j}+\ldots+x_{n j}+z_{1 j}+z_{2 j}+\ldots+z_{n j}$. As a result the $\mathrm{j}$-th industry receives bigger value added $V A_{j}$ with respect to its gross output $G O_{j}$.

Note 1. Value added is the value of the product sold less the cost of intermediate products bought from other firms. The concept of value added created by an industry is explained in the European Central Bank (ECB) Glossary [7]: "Value added (gross) is total output less the intermediate consumption". Eurostat definition [8;9]: "GDP = compensation of employees + gross operating surplus + net taxes on production and imports." The Input-Output model exposes the holistic logic of the definitions given by the ECB and Eurostat. Let us stress that value added $V A_{j}$ is the only money left for distribution in the $\mathrm{j}$-th industry after finishing the purchasing-production-selling process. This explains why the value added distribution order between workers, landlords, enterprises owners, money lenders-bankers and government established in the state is always a hot discussion topic and sometimes leads to social movements. Unfortunately, WIOD does not explore the structure of value added, therefore, WIOD does not allow to investigate the distribution of created wealth between different economic agents.

Note 2. The balancing equations allow to construct an input-output model and introduce a number of theoretical indicators with some significant economical content. We have presented a number of papers $[6 ; 10]$, which examine in detail the theoretical methods used in input-output research, and in order to be reader friendly, we have also illustrated theoretical content with simple numerical examples. The readers are kindly appealed to get acquainted with the chapter "Materials and methods" in the open access papers $[11 ; 12]$ which can be easily accessed. 
Note 3. It is handy to use the codes of industries in the text. The codes and descriptions used in NIOT are given in paper [11], table 7. Since industries in NIOT according to the International Standard Industrial Classification are strictly defined and international, we appeal to colleagues to employ the NIOT codes on a regular basis for more unified and precise scientific understanding of the notion of each industry.

\section{Results and discussion}

1. In the Baltic States and Finland the industry M72 is one of the smallest (see Table 1).

In Latvia in 2014, the industry's M72 gross output 195.96 equals to only $0.30 \%$ of the national economy total gross output 64725.66. (Values are measured in millions of US dollars.)

Ten smallest Latvian industries measured by the current industry's

Table 1 gross output as percentage of total gross output:

$[G O$ (industry) / GO(total $)] \cdot 100 ; 2014$

\begin{tabular}{|c|c|c|c|c|}
\hline Code & EST & FIN & LVA & LTU \\
\hline C19 & 0.70 & 2.49 & $\mathbf{0 . 0 1}$ & 9.73 \\
\hline A03 & 0.20 & 0.05 & $\mathbf{0 . 1 2}$ & 0.07 \\
\hline E36 & 0.28 & 0.18 & $\mathbf{0 . 1 5}$ & 0.25 \\
\hline C30 & 0.16 & 0.42 & $\mathbf{0 . 2 0}$ & 0.27 \\
\hline J58 & 0.33 & 0.82 & $\mathbf{0 . 2 5}$ & 0.27 \\
\hline C29 & 0.76 & 0.38 & $\mathbf{0 . 2 7}$ & 0.34 \\
\hline H50 & 1.21 & 0.66 & $\mathbf{0 . 2 8}$ & 0.28 \\
\hline C17 & 0.51 & 3.38 & $\mathbf{0 . 2 9}$ & 0.62 \\
\hline J59_J60 & 0.43 & 0.46 & $\mathbf{0 . 2 9}$ & 0.22 \\
\hline M72 & $\mathbf{0 . 6 6}$ & $\mathbf{0 . 5 6}$ & $\mathbf{0 . 3 0}$ & $\mathbf{0 . 1 1}$ \\
\hline
\end{tabular}

2. Excerpts from NIOT 2014 concerning industry's M72 expenditures and revenues in current prices, expressed in millions of US dollars.

Tables 2 and 3 include the general indicators that describe M72 intermediate consumption. Tables 4 and 5 show the main allocation indicators.

Table 2

Industry's M72 expenditures

in EST, FIN, LVA, LTU

\begin{tabular}{|c|l|c|c|c|c|}
\hline Code & \multicolumn{1}{|c|}{ Description } & EST & FIN & LVA & LTU \\
\hline- & Intermediate consumption (domestic) & 65.43 & 582.81 & 15.91 & 13.88 \\
\hline- & Intermediate consumption (imports) & 28.90 & 126.86 & 7.48 & 9.85 \\
\hline II_fob & Total intermediate consumption & 94.33 & 709.67 & 23.39 & 23.72 \\
\hline GVA & Gross value added at basic prices & 267.02 & $2,163.88$ & 172.56 & 69.91 \\
\hline VA & Net value added at basic prices & 264.23 & $2,095.04$ & 171.53 & 68.08 \\
\hline GO & Output at basic prices & 361.35 & $2,873.55$ & 195.96 & 93.63 \\
\hline
\end{tabular}

Industry's M72 expenditures in EST, FIN, LVA, LTU

Table 3 with respect to monetary unit of output

\begin{tabular}{|c|l|c|c|c|c|}
\hline Code & \multicolumn{1}{|c|}{ Description } & EST & FIN & LVA & LTU \\
\hline- & Intermediate consumption (domestic) & 0.1811 & 0.2028 & 0.0812 & 0.1482 \\
\hline- & Intermediate consumption (imports) & 0.0800 & 0.0441 & 0.0382 & 0.1052 \\
\hline II_fob & Total intermediate consumption & 0.2610 & 0.2470 & 0.1194 & 0.2534 \\
\hline GVA & Gross value added at basic prices & 0.7390 & 0.7530 & 0.8806 & 0.7466 \\
\hline VA & Net value added at basic prices & 0.7312 & 0.7291 & 0.8754 & 0.7272 \\
\hline GO & Output at basic prices & 1.0000 & 1.0000 & 1.0000 & 1.0000 \\
\hline
\end{tabular}


Industry's M72 final demand in EST, FIN, LVA, LTU

Table 4

\begin{tabular}{|c|c|c|c|c|c|c|c|c|}
\hline Code & $\begin{array}{c}\text { Intermediate } \\
\text { sales }\end{array}$ & $\boldsymbol{C O N S \_ \boldsymbol { h }}$ & $\boldsymbol{C O N S \_ n p}$ & $\boldsymbol{C O N S \_ g}$ & $\boldsymbol{G F C F}$ & $\boldsymbol{I N V E N}$ & $\boldsymbol{E X P}$ & $\boldsymbol{G O}$ \\
\hline EST & 9.03 & 1.32 & 0.07 & 94.61 & 223.16 & 0.03 & 33.13 & 361.35 \\
\hline FIN & 454.79 & 15.88 & 20.78 & 194.04 & 1299.12 & 0.11 & 888.82 & 2873.55 \\
\hline LVA & 0.19 & 0.03 & 0.95 & 13.52 & 159.20 & -0.03 & 22.10 & 195.96 \\
\hline LTU & 1.15 & 1.75 & 0.00 & 0.00 & 81.86 & 0.31 & 8.56 & 93.63 \\
\hline
\end{tabular}

Code and Description:

$C O N S \_h$ (Final consumption expenditure by households);

CONS_g (Final consumption expenditure by government);

CONS_np (Final consumption expenditure by non-profit organisations serving households (NPISH));

GFCF (Gross fixed capital formation); INVEN (Changes in inventories and valuables);

EXP (Exports); GO (Gross output).

Industry's M72 final demand in EST, FIN, LVA, LTU

Table 5 with respect to monetary unit of output

\begin{tabular}{|c|c|c|c|c|c|c|c|c|}
\hline Code & $\begin{array}{c}\text { Intermediate } \\
\text { sales }\end{array}$ & $\boldsymbol{C O N S \_} \boldsymbol{h}$ & $\boldsymbol{C O N S \_ n p}$ & $\boldsymbol{C O N S \_ g}$ & $\boldsymbol{G F C F}$ & $\boldsymbol{I N V E N}$ & $\boldsymbol{E X P}$ & $\boldsymbol{G O}$ \\
\hline EST & 0.0250 & 0.0036 & 0.0002 & 0.2618 & 0.6176 & 0.0001 & 0.0917 & 1.00 \\
\hline FIN & 0.1583 & 0.0055 & 0.0072 & 0.0675 & 0.4521 & 0.0000 & 0.3093 & 1.00 \\
\hline LVA & 0.0010 & 0.0001 & 0.0049 & 0.0690 & 0.8124 & -0.0001 & 0.1128 & 1.00 \\
\hline LTU & 0.0123 & 0.0187 & 0.0000 & 0.0000 & 0.8743 & 0.0033 & 0.0914 & 1.00 \\
\hline
\end{tabular}

3. The visualization of industry M72 characterizing indicators' GO,VA, CONS_g, GFCF dynamics in the period of 2000-2014 shows very close connections between the performance of these indicators (Figures 2, 3, 4, 5). The study shows that industry's M72 value added in EST, LVA, LTU almost completely depends on grants presented from institutions CONS_g and GFCF.

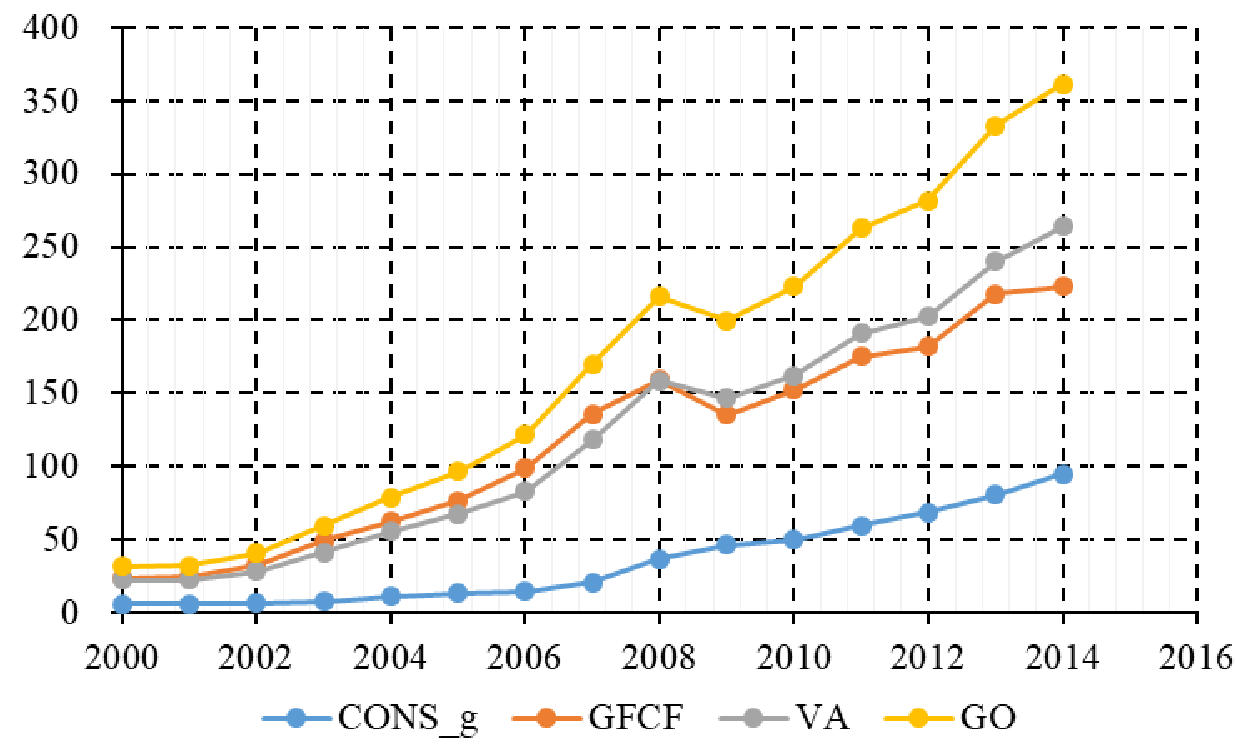

Fig. 2. Dynamics of EST industry's M72 indicators $C O N S \_g, G F C F, V A, G O$

Table 5 and Figure 6 show the industry's M72 total revenue structure in 2014. The direct forward linkage DFL shows a part of industry's M72 gross output $G O$ bought from other domestic industries as intermediate consumption. In Latvia this indicator equals to 0.0010 . Let us note that imported product of industry M72 for intermediate consumption in Latvia is also very small - only the industry $Q$ (Human health and social work activities) consumed 0.87 units of imported M72 products. Apparently, the crucially significant buyers (grantors) of industry's M72 gross product in the Baltic States are the CONS_g and GFCF. In FIN sales to CONS_g and GFCF equal to $52 \%$ from GO. 


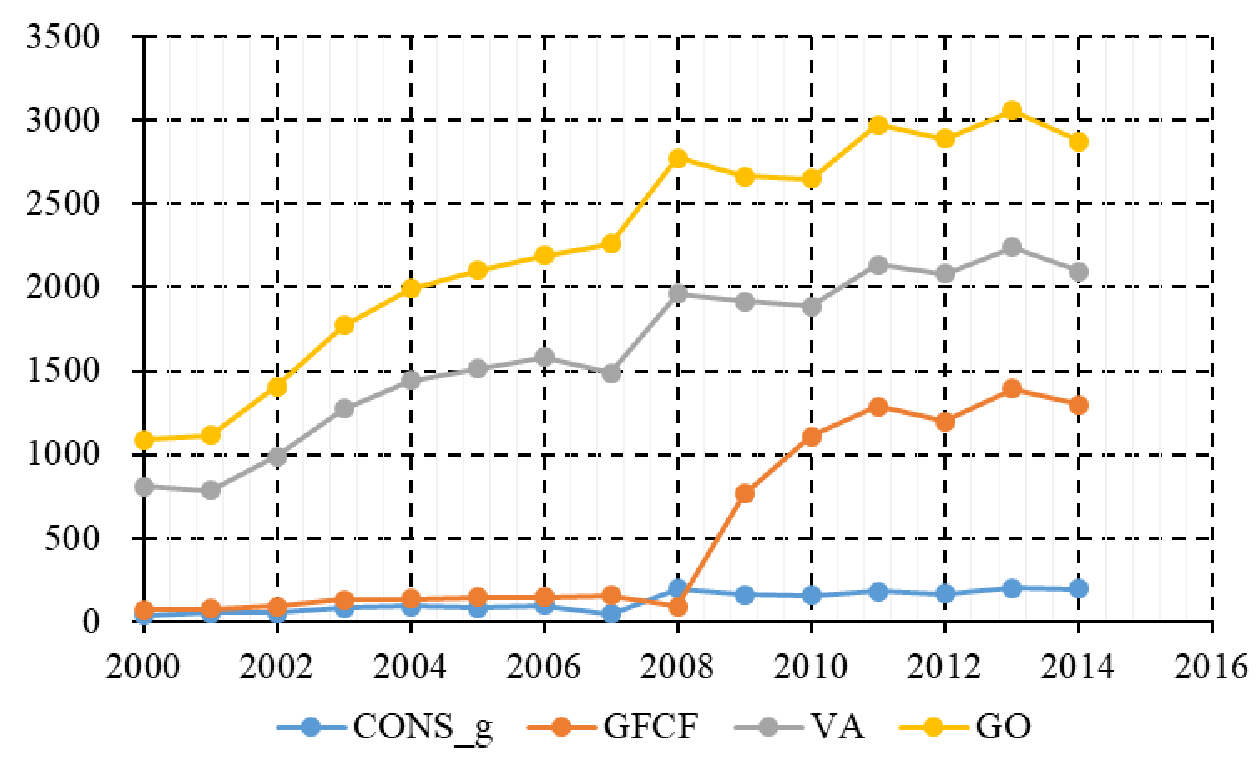

Fig. 3. Dynamics of FIN industry's M72 indicators CONS_g, GFCF, VA, GO

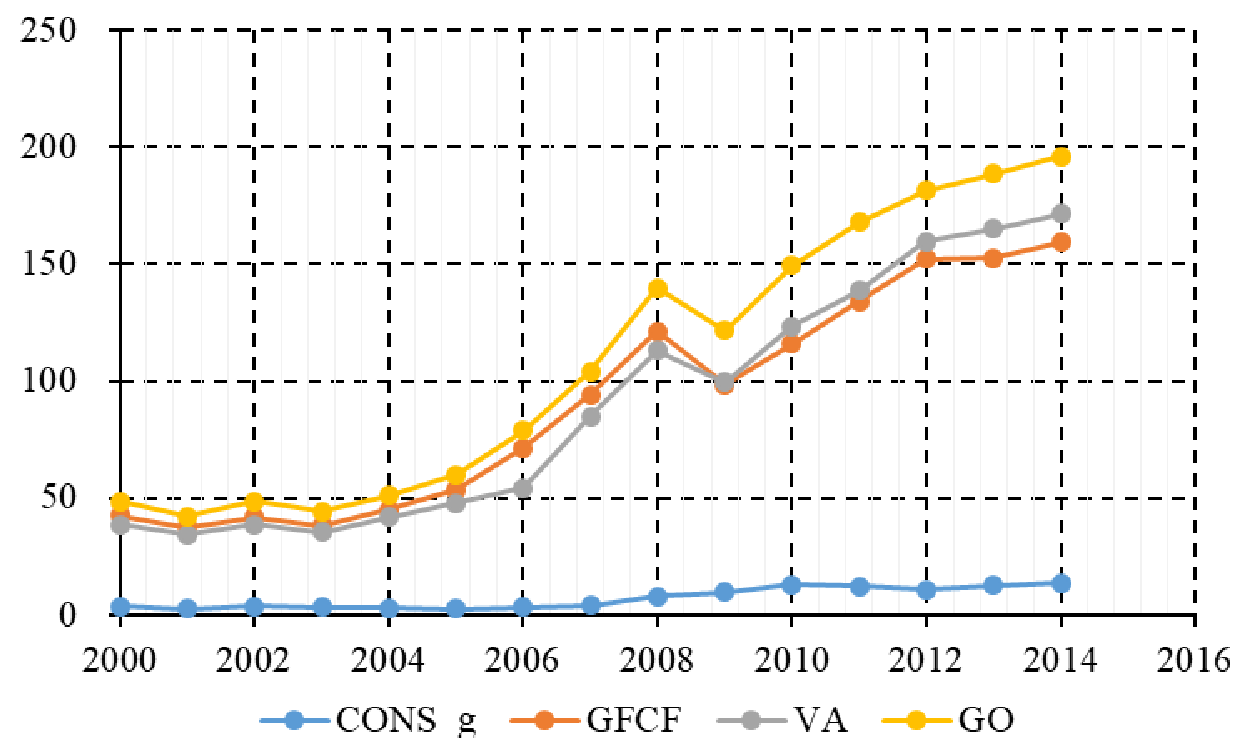

Fig. 4. Dynamics of LVA industry's M72 indicators CONS_g, GFCF, VA, GO

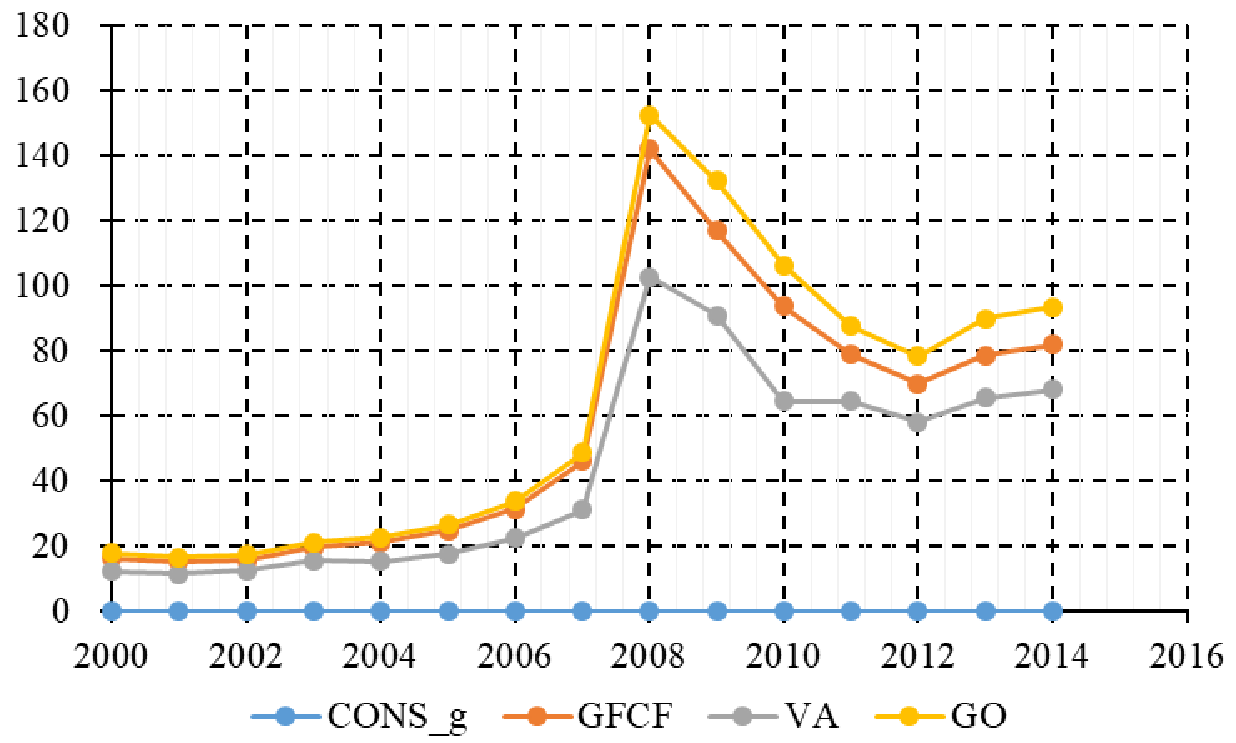

Fig. 5. Dynamics of LTU industry's M72 indicators $C O N S \_g, G F C F, V A, G O$ 


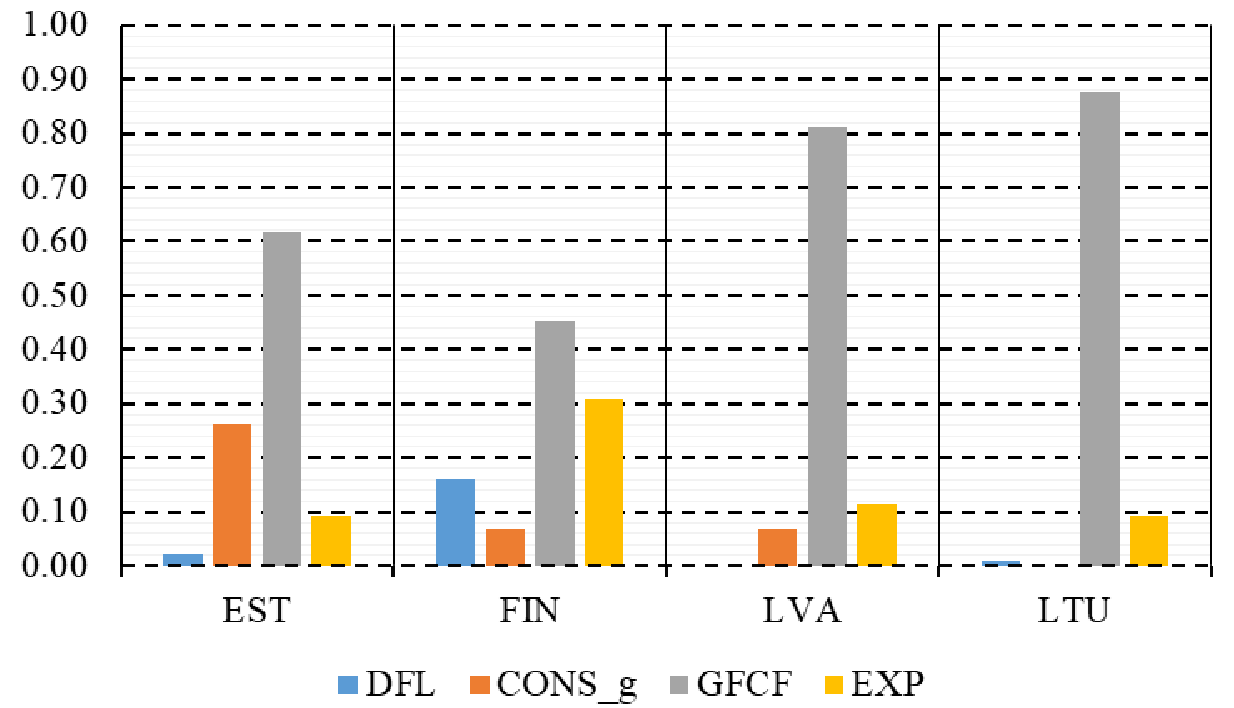

Fig. 6. Industry's M72 direct forward linkage DFL and indicators $C O N S \_g, G F C F, E X P$ as parts of gross output in 2014 in the Baltic States and Finland

4. Regressing industry's M72 value added VA against expenditures $C O N S \_g$, GFCF using 14 observed points discovers a surprisingly high correlation between the indicators VA and CONS_g, GFCF.

Table 6 contains information about regressions VA against sum CONS_g + GFCF.

For example, $V A(\mathrm{EST})=0.8330 \cdot\left[C O N S \_g+G F C F\right]-5.7291 ; R=0.9993$.

Figures 7, 8, 9, 10 show the corresponding correlation diagrams.

Table 7 contains information about regressions VA against (CONS_g, GFCF).

For example, $V A(E S T)=1.0643 \cdot C O N S \_g+0.7346 \cdot G F C F-2.3189 ; R=0.9997$.

Table 6

Regressions VA against $\left(C O N S \_g+G F C F\right)$

\begin{tabular}{|c|c|c|c|c|}
\hline Parameter & EST & FIN & LVA & LTU \\
\hline Intercept & -5.7291 & 1175.3649 & -10.8166 & 0.3109 \\
\hline$C O N S \_g+G F C F$ & 0.8330 & 0.6664 & 1.0308 & 0.7602 \\
\hline Multiple $R$ & 0.9993 & 0.8286 & 0.9953 & 0.9926 \\
\hline
\end{tabular}

Regressions VA against (CONS_g, GFCF)

\begin{tabular}{|c|c|c|c|c|}
\hline Parameter & EST & FIN & LVA & LTU \\
\hline Intercept & -2.3189 & 786.0152 & -9.5127 & 0.3109 \\
\hline CONS_g & 1.0643 & 6.3018 & 2.4836 & 0.0000 \\
\hline$G F C F$ & 0.7346 & 0.1469 & 0.9024 & 0.7602 \\
\hline Multiple $R$ & 0.9997 & 0.9356 & 0.9965 & 0.9926 \\
\hline
\end{tabular}

Regressions with high correlation allow us to estimate the marginal influence of CONS_g, GFCF expenditures to the industry's M72 value added (ceteris paribus).

For example, Table 7 shows that for LVA in the period of 2000-2014, on average, each additional unit of CONS_g expenditures results in VA increasing by 2.48 units. At the same time, each additional unit of GFCF results in only 0.90 units increasing in VA. We should note that such a difference definitely indicates the more inefficient use of the GFCF grants, when compared with CONS_g purchases.

Table 6 shows that in LVA during the period of 2000-2014, on average, each additional monetary unit of received grants leads to a VA increase by 1.03 monetary units (ceteris paribus). 


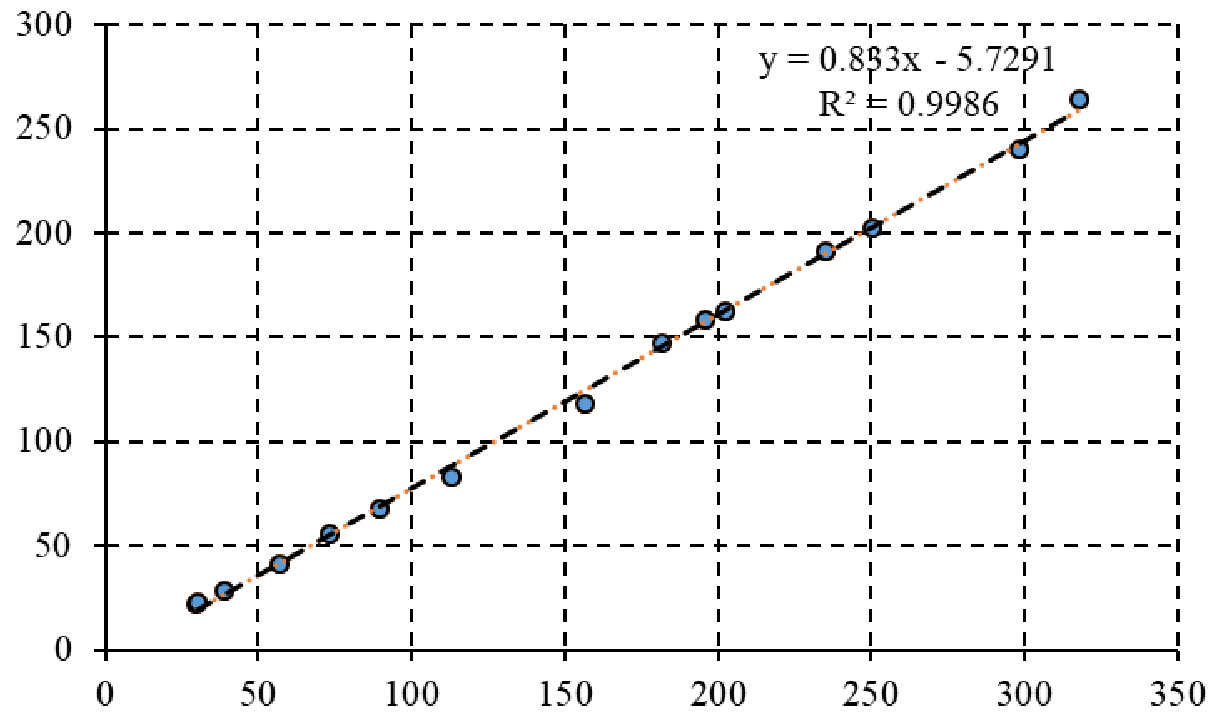

Fig. 7. EST correlation diagram $\left(C O N S \_g+G F C F ; V A\right)$

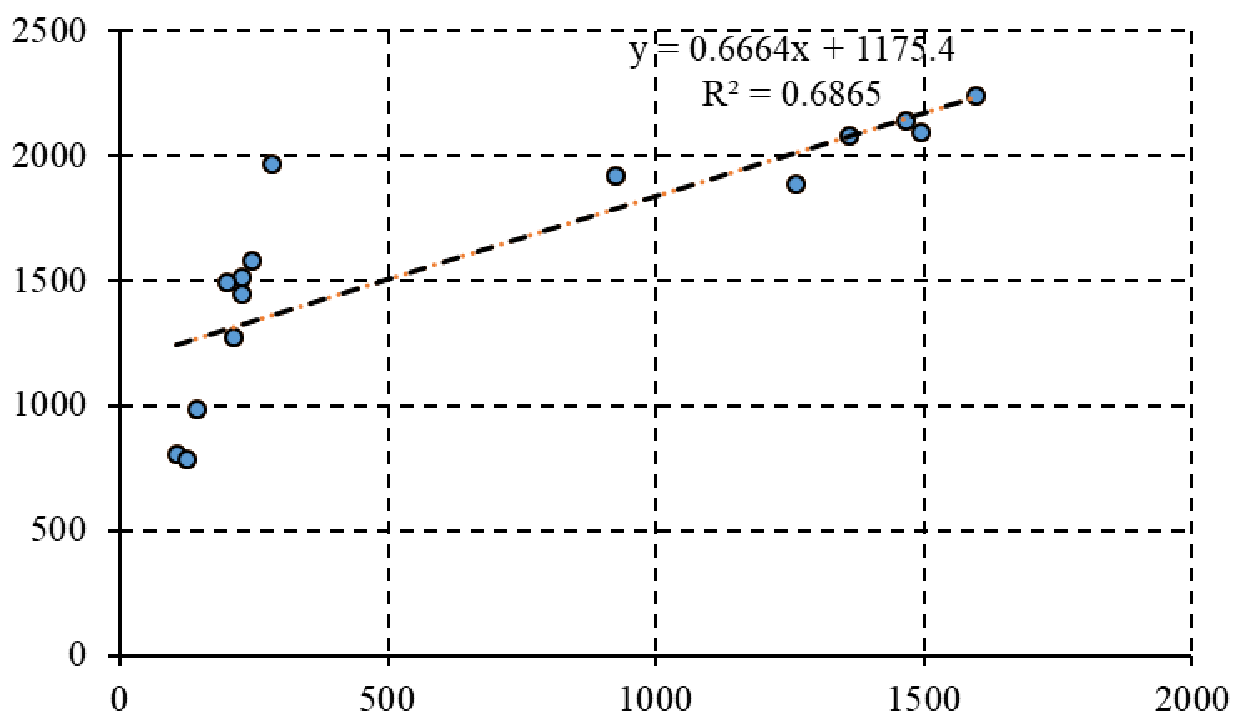

Fig. 8. FIN correlation diagram $\left(C O N S \_g+G F C F ; V A\right)$

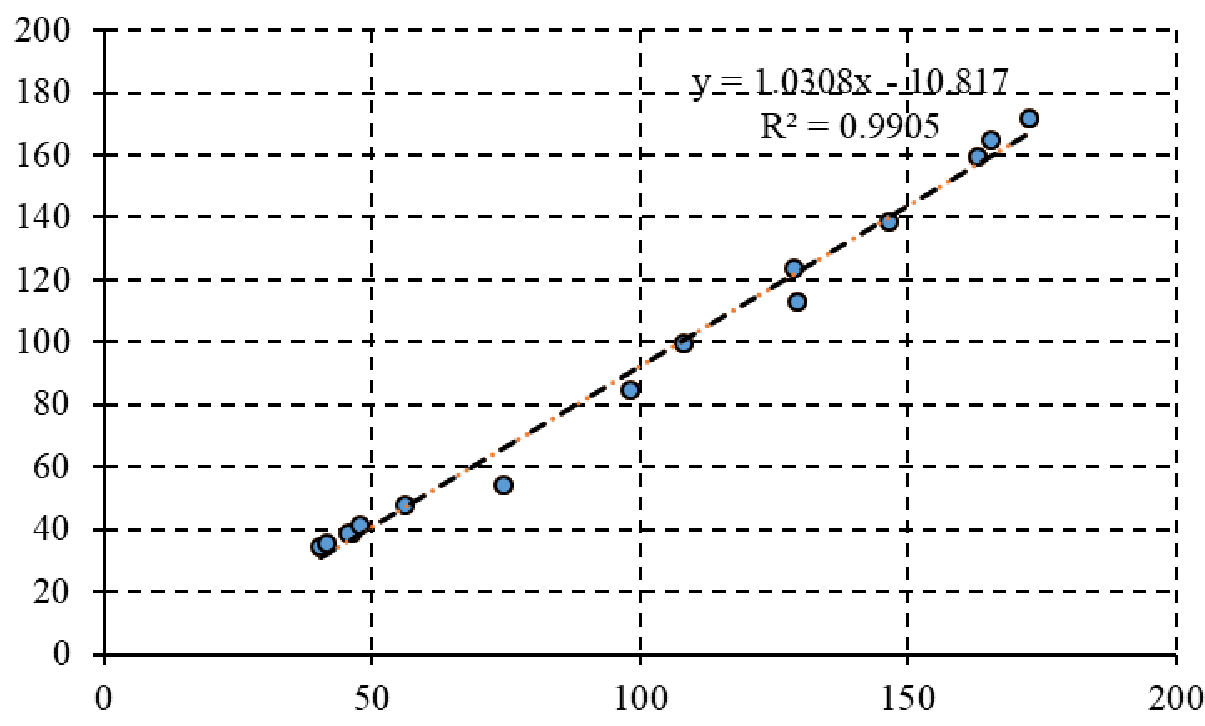

Fig. 9. LVA correlation diagram $\left(C O N S \_g+G F C F ; V A\right)$ 


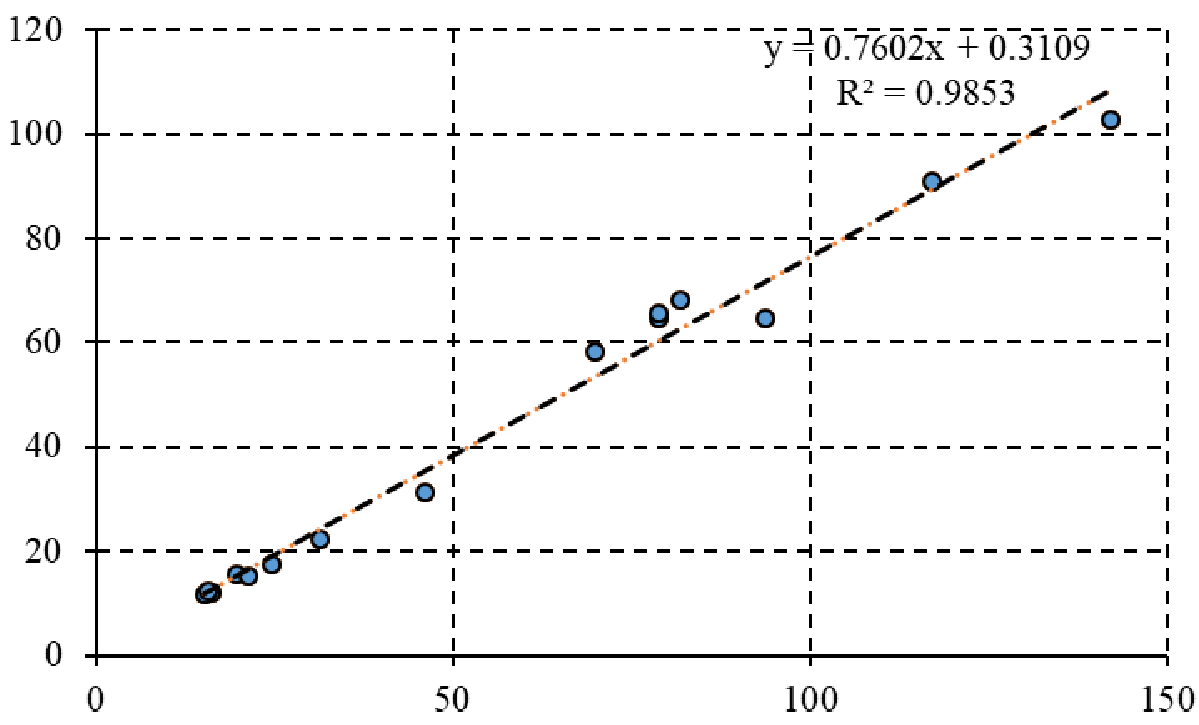

Fig. 10. LTU correlation diagram $\left(C O N S \_g+G F C F ; V A\right)$

5. Table 8 indicates the values of industry's M72 direct backward linkages DBL, total backward linkages TBL, direct forward linkages DFL, total forward linkages TFL in the Baltic States and Finland in 2014.

Table 8

Industry's M72 direct backward linkages, total backward linkages, direct forward linkages, total forward linkages in the Baltic States and Finland; 2014

\begin{tabular}{|c|c|c|c|c|}
\hline 2014, M72 & EST & FIN & LVA & LTU \\
\hline DBL & 0.18 & 0.20 & 0.08 & 0.15 \\
\hline TBL & 1.26 & 1.32 & 1.15 & 1.20 \\
\hline DFL & 0.02 & 0.16 & 0.00 & 0.01 \\
\hline TFL & 1.03 & 1.23 & 1.00 & 1.02 \\
\hline
\end{tabular}

The economic implications of these indicators are described in [7]. For example, the DBL $=0.08$ for LVA equals to the sum of intermediate consumptions of M72 with respect to one monetary unit of gross output. Compared with EST, FIN, LTU, one monetary unit of M72 gross output in LVA requires smaller expenditures (smaller intermedia consumption) for production, e. g. scientific research and development in LVA are cheaper than in other countries of reference. TBL $=1.15$ shows the necessary increase in the sum of total gross output to balance economy, in case if M72 increases its final demand by one monetary unit. This conclusion indicates a relatively small impact on the rest national industries caused by the value added increase in M72. Namely, if the industry M72 would be able to increase its value added, when value added of all the other industries remains unchanged, the required balanced growth of all rest national industries gross outputs to ensure economic equilibrium is not unrealistic and can be attained.

The calculated indicators DBL, TBL show that in all the countries of reference intermediate consumption of M72 is not the factor what sufficiently hinders increase in the final demand. The most important obstacle for increasing the industry's M72 final demand is the week capability to sell its product on the domestic or foreign markets.

The zero value DFL $=0.00$ is an evil omen we discussed before: Latvian industries do not buy the product of the industry "Scientific research and development". TFL $=1.00$ shows that increasing VA in M72 by one monetary unit does not cause any associated impact on other industries, but for balancing purposes the M72 gross output itself needs to be increased by only one monetary unit. At the same time, mass media, public discussions, speeches of key figures and academic studies usually urge "to build on science bounded economy with high value added as far as possible". No doubt, Latvian producers have bought and applied products developed through commercialized scientific achievements, for example, a lithium-ion batteries were developed by the Nobel Prize winners in Chemistry in 2019 John B. Goodenough, M. Stanley Whittingham, Akira Yoshino and then 
commercialized by Sony. However, it should be noted that the zero value DFL $=0.00$ and value $\mathrm{TFL}=1.00$ may also indicate inefficiency of the industry M72 in Latvia. Let us stress that Figure 1 created by Timmer, Dietzenbacher, Los, Stehrer, \& de Vries is also aimed at comparing the share of the intermediate consumption from the total output of M72 as an indicator of usefulness and demand of industry's M72 product directly in the real national economy. More and more people in Latvia understand that it is necessary to increase the sales of industry's M72 product. For example, Kaspars Rožkalns, Director General at the Investment and Development Agency of Latvia (LIAA), asserts (NRA 14.02.2020): "In order to increase funding of science, we must commercialize products of science".

6. Taking into account that industry's M72 intermediate consumption is not an obstacle for VA increase, the author of the article has decided at first not to pay attention to the structure of M72 production expenses. Still, later it was decided to inspect these indicators. Table 9 shows M72 interindustry coefficients ordered according to the nine biggest LVA coefficients. It is not a surprise that purchases of D35 (electricity, gas, steam and air conditioning supply) in LVA are many times bigger than in other countries of reference. Indeed, the Latvian mandatory procurement public service obligation fee (in Latvian - Obligātā Iepirkuma Komponente, OIK) undermines competitiveness of the Latvian economy. It even has some impact on the industry's M72 costs. After the parliamentary (Saeima) elections of 2018, the new political forces called OIK a fraud. The final report of the parliamentary OIK investigation committee contains a following harsh conclusion about OIK swindle (TVNET/LETA 19. 02.2020): "The system of mandatory procurement public service obligation fee is an example of how all direct or indirect stakeholders - the Ministry of Economics, Ministry of Justice, Cabinet of Ministers, State Chancellery, law enforcement agencies, the Parliament and presidents had become blind and deaf with respect to the obvious violations, which ensured existence of the it for so many years. The OIK scheme is linked to the deliberate behaviour of the national governmental apparatus under an erroneous regulatory framework, though knowing the potential consequences." (Our translation.)

Table 9

Industry's M72 intermediate domestic consumption with respect to one monetary unit of gross output in the Baltic States and Finland in 2014 ordered by the nine biggest in Latvia

\begin{tabular}{|c|l|c|c|c|c|}
\hline Code & \multicolumn{1}{|c|}{ Description } & EST & FIN & LVA & LTU \\
\hline D35 & $\begin{array}{l}\text { Electricity, gas, steam and air conditioning } \\
\text { supply }\end{array}$ & 0.0124 & 0.0059 & $\mathbf{0 . 0 3 4 9}$ & 0.0157 \\
\hline M69_M70 & $\begin{array}{l}\text { Legal and accounting activities; activities of } \\
\text { head offices; management consultancy activities }\end{array}$ & 0.0060 & 0.0055 & $\mathbf{0 . 0 0 8 1}$ & 0.0125 \\
\hline J61 & Telecommunications & 0.0031 & 0.0040 & $\mathbf{0 . 0 0 4 2}$ & 0.0052 \\
\hline H49 & Land transport and transport via pipelines & 0.0107 & 0.0171 & $\mathbf{0 . 0 0 3 9}$ & 0.0007 \\
\hline L68 & Real estate activities & 0.0196 & 0.0407 & $\mathbf{0 . 0 0 3 6}$ & 0.0021 \\
\hline C18 & Printing and reproduction of recorded media & 0.0011 & 0.0002 & $\mathbf{0 . 0 0 2 8}$ & 0.0001 \\
\hline F & Construction & 0.0053 & 0.0056 & $\mathbf{0 . 0 0 2 4}$ & 0.0241 \\
\hline N & Administrative and support service activities & 0.0120 & 0.0131 & $\mathbf{0 . 0 0 2 3}$ & 0.0010 \\
\hline
\end{tabular}

7. From the economic point of view, sales on the market have to be generally seen as actions increasing total social surplus. Of course, asymmetric information, cheating and fake goods can occur on the market, but competitive economic agents are fighting for their benefit. It is difficult to imagine products of fundamental science, for example, investigations of the Sun sold on the market. Therefore, grants for fundamental science are an objective necessity. At the same time, purchases by non-market institutions CONS_g and GFCF in the form of grants represent real corruption risks. To estimate the efficiency of CONS_g and GFCF expenditures, we must take into account a broad social and economic context, including state capture indications, which are not favourable for Latvia. State capture seeks to influence the legislative and social norms, in order to protect some specific private interests. The fact established by the parliament committee and stated as being totally "blind and deaf" with respect to the obvious fraud of OIK is a glaring example which describes the Latvian ethical environment. We see "blindness and deafness" as a latent corruption symptom, which may be related to many negative phenomena in Latvia, including purchasing of M72 products without any objective 
assessment of its quality. Let us stress that the government and different other institutions are not the subjects. Subjects are only individuals maximizing their utility according to subjective preferences. The decision-making mechanism in groups is often based on the Stackelberg-Nash equilibrium, where an important role is played by different coalitions. In Latvia stable antisocial Stackelberg-Nash equilibrium exists in different areas starting from the late Soviet period, but some new antisocial equilibria have also appeared during the last 30 years. A simplified explanation of such equilibria is widely known: "That is a fault of the system and I personally can do nothing to improve it". Indeed, it is not easy to understand the nature of Stackelberg-Nash equilibria and to find tools for surmounting the antisocial equilibria. Serious scientific investigations of such equilibria ask for the application of a professional game theory, unfortunately, almost never met in Latvia, which is a sign of weakness of education in management science education. Any quality control system is based on the existence of goal-directed standards and objective measurements of how quality meets the defined standards. Absence of a fair quality control system implies a risk of latent corruption. There are many of examples, for example, electronic information systems e-school, e-health worth approximately ten million euros. From the point of view of the economy, this is a very unfavourable situation: as government buys this sum of money paid for the respective projects, this forms industry's value added, while in fact, the products of these projects are useless garbage.

The most important and easy way of diagnosing wrong phenomena in public procurement related to the products of the industries M72 and P85 (Education) is absence of standards and measurements, therefore these products can be disqualified from experience good to the credence good and consequently a moral hazard arises. In Latvia scientific quality of research papers are as a rule measured carelessly. Our conclusion is based on hundreds of real examples concerning the subindustry M72.2 (Research and experimental development on social sciences and humanities). We assert, with full responsibility, that adequate external evaluation of student knowledge does not exist at least for half a century in Latvia. At the same time, any ideas to introduce comprehensive evaluation of student knowledge before they graduate from universities are considered inadequate. The appraisal of a professor or lecturer is of utmost significance and nobody is allowed to doubt that appraisal. This unacceptable from the economic point of view as only the producer is allowed to assess the quality of product. According to the management axiom, when there is no external control of the quantity and quality of the product, the respective organisation is posed to the risk of stagnation, as from the point of view of management science it would be naive to rely on the integrity of economic agents. The quality of the product is usually related to the cost of production: the lower the quality, the lower the average cost. If the producer does not give a guarantee to the quality of the product and cannot be penalised for a poor product, then the producer has a strong incentive to lower the quality of the product to a minimum possible level, as the market price does not react to a latent lack of quality.

Thus, the market for credence good is subject to the hidden moral hazard posed to the buyer by the producer. The Nobel Prize laureate in economics, George Akerlof, explained the destructive role of asymmetric information in the market by means of the model of the market for plums and lemons [13]. Asymmetric information in the market respectively leads to mass production of fake goods and to confidence crisis in terms of a broad Nash equilibrium.

As a result, the Latvian university diplomas for higher education are granted to persons with an extremely low level of knowledge. Each school is allowed to establish its own education standards and this is called academic sovereignty. Diplomas from high-standard state documents which should certify acquisition are transformed into fakes. Government purchases products of the industries M72 and P85 and spends taxpayers' money while remaining "blind and deaf" as regards lawfulness of Latvian state diplomas.

We have to stress that the documents prepared under the planned higher education reform in 2020 also do not prescribe any standards and measurements for student knowledge. Significantly, during the discussions such concepts as knowledge quality, knowledge audits were not discussed at all. Instead, the slogan "Let us raise the higher education quality!" was repeated for a thousand times. Indeed, this reminds us of some comedies of Nikolay Gogol (Николай Гоголь).

How could a reform of higher education be possible, when it is not defined clearly what the quality of student knowledge means and how to measure that quality of knowledge? How can we estimate the usefulness of activities, when the general ultimate aim is not clearly stated? 
People connected with business cannot understand actions without clearly defined goals. This is why Jānis Endziņ̌s, Chairmen of the Latvian Chamber of Commerce and Industry, during the discussion with the Government of Latvia on 18.02.2020 expressed his concerns regarding the margin of 1000 students as a criterion for higher education college. What is the source of this criterion? If the authors of the plan have no clearly defined goals, it is not possible to judge what actions are necessary and acceptable.

The planned higher education reform in Latvia is a pitiful example, which illustrates the weakness of education (P85) and science (M72) management by public government. This plan lacks a sound structure and does not correspond to the requirements known in management science. Why do they disregard the keywords "standards and measurement"? Operations research and Management science ask at least for: (1) a clear and detailed description of the goals of the respective actions; (2) methods and tools to measure the progress towards the targets; (3) clearly defined duties and responsibilities of the subjects involved in the implementation phase; (4) methods and tools to control actions of the subjects involved in the process and to correct their actions and the plan itself, if necessary (managerial backwards links).

The author has studied the reasons of the industry's "Education" operational inefficiency in Latvia with help of game theory in the monograph [14].

8. We would like to shortly discuss some sufficiently addressed factors, which have influenced the industry's M72 operational inefficiency in Latvia, specifically, the case of the subindustry M72.2 (Research and experimental development on social sciences and humanities). At first, let us consider the important document of the Organisation for Economic Co-operation and Development (OECD) titled "Revised field of science and technology (FOS) classification in the Frascatti manual" and recommended as a reference material in relation to $R \& D$ expenditure of the government, higher education, PNP (Private Non-Profit) sectors and of the BE (Business enterprise) sector, and to personal data in all sectors. In this publication, chapter 5, "Social sciences", contains sub-chapter 5.2, Economics and Business. The content of this sub-chapter is clearly explained and well-grounded and based on global long-term experience:

- Economics, Econometrics, Industrial relations;

- Business and Management.

"OECD Classification - Web of Science Subject Headings" contains detailed description of 5.2: Business; Business Finance; Economics; Industrial Relations and Labour; Management; Operations Research \& Management Science.

OECD presents a perfect roadmap for M72 in Latvia.

But what happened with this excellent OECD document in our country?

First of all, Latvian officials translated the OECD document in a peculiar way:

"Pārskatītā zinātnes un tehnologijas nozaru (FOS) klasifikācija Fraskati rokasgrāmatā.

\subsection{Tautsaimniecība un uzñēmējdarbība}

- Tautsaimniecība; ekonometrija; kolektīvās darba attiecības;

- Uzñèmējdarbība un pārvaldība."

The international term "Economics" is translated as "Tautsaimniecība". Indeed, in the Soviet period universities included courses in "Tautsaimniecība". Obviously, these people have never studied "Economics". It seems that the term "Industrial Relations" is also unknown in Latvia.

After that, due to enigmatic reasons the respective agents of Latvian science administration refused to apply sub-chapter 5.2 of the OECD document and decided to introduce a specific version of sub-chapter 5.2 published in the "Legal Acts of the Republic of Latvia" on 23.01.2018. Significantly, by now this document has not been officially translated into English. We will refer to the Latvian version of 5.2 and will only comment the parts of the "improved" document.

\section{“5.2. Ekonomika un uznēmējdarbība.}

Ekonomikas teorija. Latvijas tautsaimniecība. Makroekonomika. Mikroekonomika. Finanses un kredīts. Grāmatvedības un uzskaites teorija. Ekonometrija. Statistika. Tirgzinība. Sociālā ekonomika. 
Reǵionālā ekonomika. Agrārā ekonomika. Uzñēmējdarbības vadība. Izglìtības vadība. Citas ekonomikas un uzñēmējdarbïbas apakšnozares”.

\section{"5.2. Economics and entrepreneurship.}

Theory of economics. Latvian economy. Macroeconomics. Microeconomics. Finances and credit. Accounting and bookkeeping theory. Econometrics. Statistics. Marketing. Social economics. Regional economics. Agricultural economics. Entrepreneurship management. Education administration. Other sub-industries of the economy and entrepreneurship."

First of all, let us note that "Ekonomikas teorija" is nothing else as "Economics" containing "Microeconomics" and "Macroeconomics", but "Latvijas tautsaimniecība - Latvian economy" cannot be a special science as economic rules are universal. Otherwise there would be as many sciences as countries. Similarly, "Regional economics" and "Agricultural economics" are special cases of economics.

In fact, the most surprising "innovation" is the new subject "Education administration" ("Izglītības vadība") as part of the science "Economics and entrepreneurship".

A dangerous signal for the development of Latvian social sciences is the fact that the content of 5.2 "Operations Research \& Management Science" of the OECD publication is not included in the Latvian classification. We suspect that the persons which have "improved" the OECD document are not acquainted with Operations Research \& Management Science.

A striking example concerning the classification of Doctoral degrees can be used to show the utmost disorder of the regulation of the subindustry M72.2 (Research and experimental development on social sciences and humanities) in Latvia. A discussion about the Doctoral degree in the so-called "vadībzinātne" took place in the journal Zinātnes Vēstnesis.

Pursuant to Decision No. 1-1 (17.02.1998) of the Latvian Council of Science, the academic title in "vadībzinātne" is not defined. Nevertheless, in Latvia the so-called "vadībzinātne" scientists were granted various Doctoral titles. At first, the title Dr.oec. was widely granted; then this was admitted to be a fake, as many of them admitted that they actually do not possess knowledge in economics. Then many other titles were used: Dr.man., Dr.kom., Dr.sc.administr. Academician R.Valters expressed his dissatisfaction in Zinātnes Vèstnesis on 14.05.2012 regarding this practice, as such titles are not approved by the Latvian Council of Science and thus also not by the Cabinet of Ministers.

We have to stress that fake Dr.oec. degrees during many years widely granted to hundreds of persons, which actually do not possess knowledge in economics, totally compromise the science "5.2. Economics and Business" (OECD, Frascatti manual) in Latvia. The true Dr.oec. will judge this assessment because the author is the only one who dares to formulate so harsh verity already in the monograph [14, page 140].

\section{Conclusions}

1. The industry M72 (Scientific research and development) in the Baltic States and Finland can be qualified as a small industry in terms of its gross output as a part of total gross output.

2. The product of industry M72 in Latvia is practically not sold on the market as intermediate consumption resource for the industries of the national economy. In 2014, approximately $88 \%$ of the industry's M72 gross output was bought from non-market institutions CONS_g (Final consumption expenditure by government) and GFCF (Gross fixed capital formation), therefore, the basis for value added formation in M72 is mainly grants. The operation of M72 in Latvia, generally speaking, can be qualified as inefficient.

3. The economic analysis leads to the following conclusion: the most realistic tool to increase the Latvian M72 value added is the commercialization of the products of scientific research and development in order to sell them on the domestic and foreign markets. The commercialization and the following domestic intermediate consumption and increase in final demand do not require exorbitant conditions for the rest of national economy, but at the same time lead directly to an increase in the industry's M72 value added.

4. At the same time, a sufficient pre-condition to increase the commercialization of the products of scientific research on the domestic and foreign markets is a radical improvement of industry's 
M72 management by the government, e. g. sufficiently improved supervision of how grants are allocated.

5. The main reason of long lasting insufficient higher education and scientific research quality is the lack of the objective operating results' professional and fair assessment, and the lack of the quality measurement in higher education and in the scientific research. The absence of objective measurement transforms the products of P85 (Education) and M72 (Scientific research and development) from experience goods to the credence goods. Naturally, moral hazard arises, often leading to acquisition of educational and scientific fakes. Such a situation may be qualified as anti-social Stackelberg-Nash equilibria.

6. The planned higher education and science management reforms in Latvia must include precisely defined quality concepts through the concepts of standards and measurement.

7. Our studies by applying WIOD show Latvia's underperformance in almost everything, when compared with EST and LTU. This leads to huge losses of Latvian people. One of the important reasons of Latvia's comparative failure is that people representing the Latvian government have weak education in the area of management science, which itself is the result of the long lasting higher education failure. In the opinion of the author, persons representing the Latvian government have to start serious Operations Research \& Management Science studies right now.

\section{References}

[1] Leontief W. Input-Output Economics. Second Edition. - Oxford University Press. 1986, 436 p.

[2] Ghosh A. Input-Output Approach to an Allocation System. - Economica, Vol. 25, No. 1, 1958, pp. 58-64.

[3] Miller R.E., Blair P.D. Input-Output analysis. Foundations and extensions. Second Edition. Cambridge University Press, 2013, 750 p.

[4] Timmer M. P., Dietzenbacher E., Los B., Stehrer R., de Vries G. J. An Illustrated User Guide to the World Input-Output Database: the Case of Global Automotive Production. - Review of International Economics, vol. 23, 2015, 575 p.

[5] Timmer M.P., Dietzenbacher E., Los B., Stehrer R., de Vries G.J. Review of International Economics, 23(3), 575-605, 2015 DOI: 10.1111/roie.12178.

[6] Jaunzems A. Comparative dynamic analysis of value added created by industry "Forestry and logging" in the Baltic States and Finland. 17th International Scientific Conference on Engineering for Rural Development. Proceedings, Latvia, Jelgava, 2018, pp. 1019-1028.

[7] ECB Glossary "V". [online][11.02.2020] Available at: http://www.ecb.europa.eu/home/glossary/html/glossv.en.html

[8] Glossary: Intermediate consumption [online][11.02.2020] Available at: https://ec.europa.eu/eurostat/statistics-explained/index.php/Glossary:Intermediate_consumption

[9] Glossary: Gross value added [online][11.02.2020] Available at: https://ec.europa.eu/eurostat/statistics-explained/index.php/Glossary:Value_added

[10] Jaunzems A., Balode I. Comparison of Backward and Forward Linkages for Industries in the Baltic States and Finland. 17th International Scientific Conference Engineering for Rural Development, Proceedings, Jelgava, Latvia, 2018, pp. 1029-1039.

[11] Jaunzems A. Value added created by industry "Education" in Baltic States and Finland. 18th International Scientific Conference Engineering for Rural Development, Proceedings, Jelgava, Latvia, 2019, pp. 1090-1103.

[12] Jaunzems A., Balode I. Comparative dynamic analysis of value added created by industry "Crop and animal production, Hunting and related service activities" in the Baltic States and Finland. 18th International Scientific Conference Engineering for Rural Development, Proceedings, Jelgava, Latvia, 2019, pp. 1104-1117.

[13] Akerlof G. The Market for Lemons: Quality, Uncertainty and the Market Mechanism. - The Quarterly Journal of Economics, \# 84, 1970.

[14] Jaunzems A. Šumpētera atziņas par uzṇēmēju kā ekonomikas pārmaiņu mehānismu: pro, contra, addendum (Schumpeter's findings about entrepreneurs as a mechanism of economic change: pro, contra, addendum). Zinātniskā monogrāfija akadēmiķes Raitas Karnītes zinātniskajā redakcijā. Ventspils Augstskola, ISBN 978-9984-648-67-5; 2017., 226 lpp. (In Latvian). 